\title{
KAJIAN KARAKTER WAYANG JABANG TETUKA MELALUI METODE PENELITIAN ARTISTIK
}

\author{
Febrianto Saptodewo \\ Program Studi Desain Komunikasi Visual, \\ Fakultas Bahasa dan Seni Universitas Indraprasta PGRI \\ Jl. Nangka 58 Tanjung Barat, Jakarta Selatan, 12530 \\ febrianto.saptodewo@gmail.com
}

\begin{abstract}
Abstrak
Perancangan tokoh karakter wayang jabang Tetuka dalam bentuk Wayang Purwa telah melalui berbagai proses. Proses tersebut merupakan investigasi orijinal yang dilakukan dalam upaya mendapatkan pengalaman dan pengetahuan baru di mana hal tersebut melalui riset dan sebagian besarnya melalui sarana praktik juga melalui hasil praktik. Keorijinalitas dan kontribusinya dalam ilmu pengetahuan dapat ditunjukkan melalui artefak seperti perancangan tokoh karakter jabang Tetuka dalam bentuk digital.
\end{abstract}

Kata Kunci: Jabang Tetuka, Wayang Purwa, Karakter, Tokoh, Perancangan, Digital

\begin{abstract}
Planning a cast of characters in the form of Tetuka baby Purwa shadow puppet have gone through a variety of processes. The process is carried out genuine investigations in an effort to get new experiences and knowledge where it is through research and through the means of most of the practice as well as through the practices. The Originality and contributions in science can be presented through artifacts' such as planning a cast of characters of Tetuka baby in digital form.
\end{abstract}

Keywords: Tetuka Baby, Purwa Shadow Puppet, Character, Design, Digital 


\section{PENDAHULUAN}

Bahwa sebuah pemahaman dari cara orang belajar melalui melihat, memvisualisasikan dan membuat citra visual adalah penting untuk menjelaskan mengapa berkarya seni dikualifikasikan sebagai penelitian.

Historiografi penelitian artistik bermula dari Renaisans hingga Bauhaus, di mana penelitian dilakukan dalam dan melalui praktik artistik (Borgdorff dalam Guntur, 2016: 42). Pada awal tahun 1980an penelitian berbasis praktik mulai dikembangkan di Finlandia, dan pada tahun 2000-an istilah itu berubah menjadi penelitian berarah praktik. Dengan mengadopsi peran praktik profesional dalam proses penelitiannya (Guntur, 2016: 41).

Istilah kata 'penelitian' digunakan untuk menunjuk penelitian sistematis guna menghasilkan pengetahuan baru, dan kata 'peneliti' adalah orang yang melakukan penelitian (dalam seni maupun desain). Sedangkan untuk kata 'praktik' digunakan untuk merujuk pada praktik profesional (dalam seni, desain, dll) atau pada proses yang biasa digunakan dalam praktik profesional dan praktik kreatif untuk menghasilkan karya untuk tujuan lain dibandingkan semata-mata untuk mendapatkan pengetahuan. Kata 'praktisi' dalam pada itu merujuk pada siapapun yang melakukan praktik profesional/kreatif (Niedderer and Roworth-Strokes dalam Guntur, 2016: 42)

Ketika praktik artistik tidak hanya hasil penelitian, tetapi juga sebagai wahana metodologinya, ketika penelitian berkembang dalam dan melalui tindakan menciptakan dan melakukan. Hal inilah yang membedakan penelitian artistik dari seluruh penelitian akademik (Borgdorff dalam Guntur, 2016: 47).

Menurut Julia Marshal dalam Guntur (2016: 140) praktik seni adalah penelitian. Berdasarkan konsepsi ter- sebut, maka berkarya seni adalah penyelidikan-secara khusus sebagai suatu proses belajar eksperiensial dan konstruktif di mana sintesis imajinatif dan membuat citra kreatif merupakan cara mengkonstruksi pengetahuan. Konsep dari sketsa jabang Tetuka tersebut adalah bayi raksasa dengan rambut gelungnya juga ari-ari yang belum terpotong.

Pada tiap tahap pembuatan tokoh wayang, selalu dikerjakan sesuai dengan pakem (tata cara) pengerjaan wayang kulit tradisional. Dicontohkan, pengerjaan wayang digital juga melewati proses menatah atau memahat dan menyungging atau mewarnai seperti layaknya pembuatan wayang tradisional.

Cerita maupun tokoh karakter Gatotkaca telah cukup populer di kalangan masyarakat Indonesia. Karakter Gatotkaca dapat disamakan dengan tokoh karakter Superman, dengan kemampuan yang hampir setara. Putra dari Bima yang merupakan ksatria Pandawa dengan Dewi Arimbi putri dari kerajaan raksasa Pringgandani, Gatotkaca saat kecil bernama Tetuka.

Tokoh karakter Tetuka sangatlah penting untuk dirancang karena tokoh tersebut akan menjadi pengembangan lakon atau cerita pewayangan tentang pentingnya dan penghargaan sebuah proses penempaan hidup dan ilmu pengetahuan saat berada dalam kawah Candradimuka hingga akhirnya keluar menjadi tokoh pembentukkan karakter ksatria nantinya.

Menurut Kaelola dalam konsep perancangan yang telah dipublikasikan oleh Febrianto Saptodewo pada Jurnal Desain Vol. 01 No. 02 Jan-Apr 2014 yang berjudul "Perancangan Visualisasi Tokoh Wayang Bambang Tetuka"(2014: 105), saat tokoh karakter ini lahir, kepala jabang (bayi) Tetuka konon mirip dengan buli-buli atau kendi. Keunikan dari berdasarkan literatur tersebut akan 
berubah menjadi membingungkan dan menyusahkan apabila terlalu banyak detil yang ditambahkan. Maka perancangan dibuat saat tokoh Tetuka masih bayi lengkap dengan tali pusar yang belum dapat terpotong.

Seorang filusuf Jerman Jurgen Habermas telah membedakan tiga jenis penelitian yang disebut "minat konstitutif pengetahuan".

1. Jenis disiplin yang harus memusatkan minat teknis dengan menghasilkan pengetahuan yang dapat digunakan untuk memprediksi dan mengendalikan (dan mencegah peristiwa); ilmu "empiris analitis", dengan metode eksperimental.

2. Jenis disiplin yang harus memuaskan minat praktis dengan menciptakan pemahaman fenomena budaya melalui studi teks, melalui metode hermeneutik.

3. "Ilmu tindakan sistematis" seperti ilmu ekonomi, sosial, dan politik (Guntur, 2016:119-120).

Penelitian artistik, sejalan dengan pemikiran Habermas, dibimbing oleh minat teknis dan minat praktis yang juga menggunakan metode hemeneutik. Dalam perancangan karakter jabang Tetuka minat teknis dari perancangan tersebut melakukan tatah dan sungging layaknya membuat wayang umumnya namun dikerjakan menggunakan komputer. Sedangkan minat praktisnya adalah mempermudah pengaplikasian karya seni tersebut pada media lain. Penelitian artistik lebih diarahkan kepada sesuatu yang tidak-diketahui atau sesuatu yang belum diketahui, dalam hal ini perancangan tokoh karakter jabang Tetuka bentuknya belum diketahui secara visual namun secara literatur ada. Penelitian ini menciptakan ruang terhadap apa yang tidak terpikirkan, yang tidak diduga-gagasan bahwa segala sesuatu dapat menjadi berbeda. Inilah yang oleh Beorgdorff disebut sebagai ke- mungkinan (contingency) dari penelitian artistik. (Guntur, 2016: 122). Berdasarkan teori kebudayaan Koentjaraningrat dalam Jurnal Desain Vol. 02 No. 03 yang berjudul "Mempopulerkan Cerita Pewayangan di Kalangan Generasi Muda Melalui Motion Comic" oleh Febrianto Saptodewo (2015: 149) mengenai adat istiadat, bahwa sistem nilai budaya merupakan tingkat yang paling tinggi dan paling abstrak dari adat istiadat. Perkembangan teknologi yang begitu pesat menggeser kesenian tradisional wayang, fakta ini tidak bisa dipungkiri bahwa anak-anak muda atau bahkan anak kecil di zaman ini sudah menggunakan kecanggihan teknologi seperti komputer, blackberry, televisi, ipad dan sebagainya. Dengan digitalisasi karya perancangan akan mempermudah pengaplikasiannya pada media lain.

Penelitian artistik berbeda dari berbagai jenis penelitian lain, karena sifatnya yang memfokus pada pekerja seni sebagai peneliti dan proses kreatif mereka. Penelitian artistik menempatkan praktik artistik sebagai subjek, metode, konteks, dan hasil penelitian. Pencampuran metodologi - sudut pandang beragam pendekatan yang berasal humaniora, ilmu sosial, atau ilmu dan teknologi dapat memainkan perananya sebagai sebagian peran dalam penelitian artistik, namun hal ini harus dipandang sebagai pelengkap terhadap prinsip penelitian yang dilakukan dalam dan melalui penciptaan karya seni (Beogdorff dalam Guntur, 2016: 43).

Menurut Candy dalam Guntur (2016: 17), penelitian berbasis praktik (practice-led research) merupakan investigasi orijinal yang dilakukan dalam upaya mendapatkan pengetahuan baru, di mana pengetahuan tersebut sebagian diperoleh melalui sarana praktik dan melalui hasil dari praktik itu. Klaim keorijinalitas dan kontribusi terhadap pengetahuan dapat ditunjukan melalui hasil kreatif yang dapat berupa artefak 
seperti citra, musik, desain, model, media digital, atau lainnya seperti pertunjukkan dan pameran. Sementara, signifikasi dan konteks dari klaim tersebut diuraikan dalam kata-kata, sebuah pemahaman utuh yang hanya dapat dicapai dengan referensi langsung terhadap hasil. Jika dasar kontribusi dari suatu artefak kreatif untuk pengetahuan, maka penelitian itu berbasis praktik. Dasar kontribusi perancangan ini adalah sebagai karakter untuk media pembelajaran melalui cerita pewayangan tentang sebuah proses belajar hingga menjadi seorang ksatria dan juga pemimpin kerajaan Pringgandani.

Proses kreativitas dalam berkesenian memberikan kebebasan penapsiran bagi siapa saja yang ingin mewujudkan suatu ide dalam karya. Penerapan ide ditentukan oleh konsep karya atas nilai-nilai yang terkandung di dalamnya. Nilai tersebut diterapkan ke dalam bentuk karya seni, sehingga judul, tema, dan strukturnya dapat memberikan kejelasan.

Secara metodologis, proses kreatif membentuk jalan kecil (atau bagian dari padanya) yang melaluinya pengetahuan, pemahaman, dan produk baru menjadi ada (Borgdorff dalam Guntur, 2016: 46)

Untuk pemahaman utuh dari perancangan karakter tokoh Tetuka diuraikan dalam kata-kata, sebuah pemahaman utuh yang hanya dapat dicapai dengan referensi yang didapat langsung sebagai dasar perancang hasil akhir.

\section{PEMBAHASAN}

Menggunakan media komputer wujud tokoh jabang Tetuka berdasarkan bentuk wayang Purwa dengan aplikasi software Adobe Illustrator. Wayang digital tidak hanya dapat diterapkan untuk televisi dan film bioskop, tapi juga dapat diterapkan untuk atraksi di taman hiburan dan panggung teater secara langsung. Tidak terbatas lagi pada tempat dan media layar. Aplikasi pada media juga tidak terbatas pada kulit saja, namun dapat pada media cetak maupun digital lainnya.

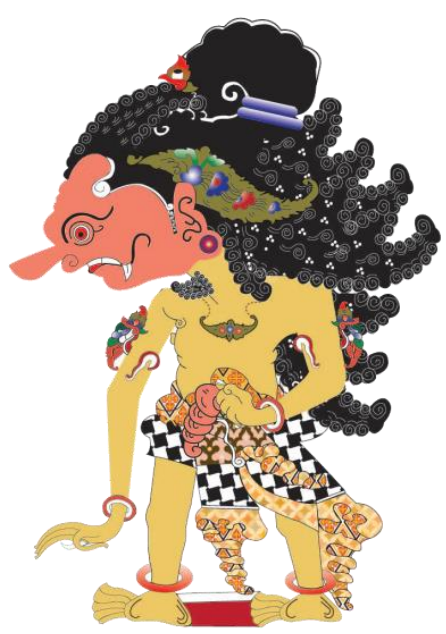

Visual Bayi/Jabang Tetuka (Sumber: F. Saptodewo)

Telah dijabarkan pula oleh Febrianto Saptodewo dalam Jurnal Desain Vol. 03 No. 03 Mei 2016 yang berjudul "Pengembangan Karakter Wayang Tetuka untuk Pengembangan Cerita saat Berada di Kawah Candradimuka" (2016: 233), Dengan berdasarkan acuan dari pustaka, maka perancangan bentuk dari karakter jabang (bayi) karakter Tetuka digambarkan bermata telengan dan mempunyai hidung berbentuk dempak. Berbeda dengan raksasa pada umumnya karena ia adalah keturunan bangsa raksasa kerajaaan Pringgadani maka ia berbudi pekerti baik. Dengan rambut yang gimbal layaknya bangsa keturunan dari ibunya, Raksasa dan saat Bima muda saat ia menyamar menjadi Jagal Abilawa. Ukuran tubuh atau bentuk wayang jabang (bayi) Tetuka lebih besar dari bentuk wayang bayi yang selama ini dalam pementasan diceritakan sebagai karakter jabang Tetuka. karena 
keturunan dari bangsa raksasa maka ukurannya lebih besar dari bayi bangsa manusia. Dengan perbedaan bentuk tersebut maka karakter Tetuka dapat lebih mudah dikenali. Dari sisi fashion karena Tetuka adalah anak dari keluarga kerajaan Pringgandani, maka ia sudah mengenakan perhiasan. Berbalut dengan kain kotak-kotak hitam putih yang identik dengan kain yang dikenakan oleh ayahnya Bima agar mempermudah pengenalan karakter dari sisi keturunannya.

Perancangan karakter jabang Tetuka melalui praktik membuat wayang, melalui proses tatah, sungging dan pengetahuan menggunakan komputer dengan aplikasi Adobe Illustrator. Halhal tersebut merupakan gagasan kolektif yang dapat mencakup karakter jabang Tetuka berdasarkan bentuk Wayang Purwa yang berorientasi pengetahuan membuat wayang dan mempraktikkannya (practice oriented research), penelitian dalam seni.

Praktik seni memenuhi syarat sebagai penelitian jika tujuannya adalah untuk memperluas pengetahuan dan pemahaman kita dengan melakukan investigasi orijinal dalam dan melalui objek seni juga proses kreatif (Borgdorff dalam Guntur, 2016: 88). Penelitian seni dimulai dengan mengarahkan pertanyaan pada narasumber yang berkaitan dengan perancangan tokoh karakter jabang Tetuka maupun wayang Purwa, metode wawancara dilakukan di Museum Wayang, dengan Bapak Soemardi selaku kurator museum, serta narasumber yang berprofesi sebagai Dalang pewayangan untuk mendapatkan data pendukung proses penciptaan Peneliti menggunakan metode eksperimen dengan membuat sketsa alternatif karakter jabang Tetuka disertai proses asistensi dan hermeneutik guna untuk mengungkapkan dan mengartikulasikan pengetahuan tak terucap yang disituasikan dan diwujudkan dalam karya seni dan proses artistik tertentu.

Smith dan Dean dalam Guntur (2016: 131), menandaskan bahwa karya seni seringkali mewujudkan pengetahuan yang dapat digeneralisasi, yakni dapat diaplikasikan pada beberapa proses lain atau peristiwa yang dikaji dan ditransfer, yakni dapat dipahami dan digunakan orang lain sifatnya sama. Hasil perancangan karakter jabang Tetuka dapat diaplikasikan pada media lain, dikarenakan sifatnya yang berupa digital, selain itu karakter jabang Tetuka menjadi acuan beberapa mahasiswa Tugas Akhir untuk membuat karya mereka dalam bentuk media komik maupun animasi.

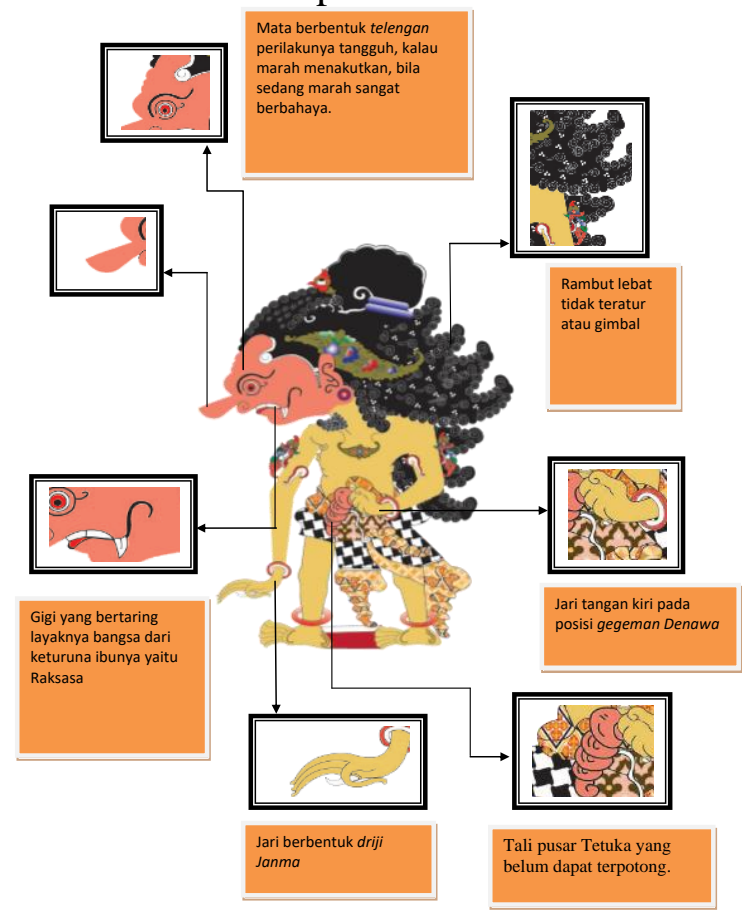

Menurut P. Strandman dalam Guntur (2016: 19), pada prinsipnya bagian-bagian dari praktik seni adalah penelitian, karena hal tersebut merupakan investigasi. Melakukan pengamatan secara langsung dan mencari keterangan dari informasi yang mendukung data yang mendukung perancangan. Setelah data terkumpul dianalisis serta dibahas dan diuraikan berbagai bagian, sehingga mendapat gambaran atau konsep yang jelas bentuk dari tokoh karakter jabang 
Tetuka sebagai sumber acuan perancangan dalam bentuk digital.

Aplikasi ketrampilan yang telah dipelajari merupakan refleksi dari 'penelitian', dari 'teorisasi'. Menurut Baluvelt dalam Guntur (2016: 19), 'Bukan sesuatu yang salah satu dilakukan atau sesudah karya dibuat, akan tetapi hal yang paling penting adalah proses pembuatannya'. Setelah mengamati dan mempelajari membuat wayang, maka perancang mengaplikasikan dalam media digital dengan melalui proses tatah dan sungging.

Lebih jauh lagi praktik perancangan tokoh jabang Tetuka dalam wilayah penelitian melibatkan beberapa gubahan sebagai sesuatu yang tersirat dari kekhususan pada pengembangan lakon (cerita) lahirnya Gatotkaca di mana karya dikerjakan, dan menggali beberapa kompleks relasi dalam karya, yaitu bentuk wayang Purwa yang merupakan keluarga dari karakter jabang Tetuka, dan relasi karya pada konteks di luarnya yaitu sebagai bahan pengajaran tentang pentingnya sebuah proses dalam suatu pembentukkan.

Labelisasi penelitian seni kreatif dan pertunjukkan seperti: penelitian dalam seni dan desain; penelitian berbasis praktik, penelitian berarah praktik; penelitian berbasis studio; penelitian berbasis seni; praktik sebagai penelitian; penelitian seni; penelitian melalui praktik; dan penelitian artistik.

Penelitian seni (dan desain) melibatkan beragam metode, utamanya adalah visual, yang berasal dari praktik atau diadaptasi dari paradigma penelitian lain untuk penelitian seni (Guntur, 2016: 131-132). Dikarenakan hampir semua disiplin ilmu seperti: ilmu alam,fisika, ilmu sosial, humaniora, seni kreatif, dan pertunjukkan menggunakan visual untuk berbagai tujuan seperti:

1. Mengumpulkan dan/atau menghasilkan data
2. Mengorganisasikan, menggambarkan, dan mengkomunikasikan ide

3. Menjelaskan atau memahami suatu fenomena atau situasi

4. Menawarkan dan membujuk

5. Mengevaluasi, manganalisis, dan menginterpretasi

6. Mengubah dan mengkomunikasikan temuan (Gray dan Marlins dalam Guntur, 2016: 131)

Dalam dunia desain, penelitian yang arah utamanya untuk pemahaman baru tentang praktik, maka penelitian itu berarah praktik maka label yang diberikan terhadap pengertian tersebut adalah penelitian melalui desain. Dengan menggunakan penelitian berarah praktik merupakan mode penyelidikan di mana praktik desain digunakan untuk menciptakan suatu bukti dasar terhadap sesuatu didemonstrasikan atau ditemukan (Guntur, 2016: 21-22). Hal ini perancangan tokoh jabang Tetuka menggunakan penelitian berarah praktik guna untuk menemukan bentuk dari karakter jabang Tetuka yang berbasis wayang Purwa dan mengkomunikasikan pengetahuan baru bagi para pecinta wayang dan teori yang digunakan dalam perancangannya berasal dari praktik desain yang dilaluinya.

Penelitian berarah praktik melihat karya seni sebagai bentuk penelitian yang kemudian dapat didokumentasikan, diteorikan, dan digeneralsasikan. Dengan melakukan penelitian berbasis seni wayang Purwa, memungkinkan dapat menghargai sebuah karya seni dalam dan dari dirinya sendiri dengan cara mempresentasikan pemahaman tentang kehidupan manusia. Karya seni yang dibuat melalui suatu proses yang mencerminkan proses penyelidikan dan berakhir dalam bentuk produk wayang digital tokoh karakter jabang Tetuka.

Borgdorff dalam Guntur (2016: 35), mengemukakan bahwa tidak adanya pemisahan fundamental antara teori dan 
praktik dalam seni. Maka tidak ada praktik seni yang tidak menyertakan pengalaman, keyakinan, dan sejarah; sebaliknya tidak ada akses teoretis terhadap, atau interpretasi dari, praktik seni yang tidak membentuk secara parsial ke dalam seni. penelitian dalam seni oleh karena itu mengartikulasikan beberapa pengetahuan yang mewujud atau menubuh melalui proses kreatif dan dalam objek seni. penelitian berbasis seni memungkinkan peneliti menggunakan perspektif dan mengembangkan sensitivitas sepanjang waktu terlibat dalam seni dalam upayanya melahirkan dan menyajikan data.

\section{SIMPULAN}

Perancangan tokoh karakter jabang Tetuka dengan metode penelitian artistik melalui berbagai proses penelitian hingga akhirnya terbentuklah produk wayang Purwa pada media digital.

Praktik seni sebagai penelitian banyak menyumbang teori dan praktik dalam pendidikan seni. Penelitian artistik dalam seni, aktivitas seni dan karya seni merupakan sumber data penelitian. Demikian juga apa yang dihasilkan dari padanya adalah sumber data penelitian.
Setelah proses kreatif berakhir dan artefak akhirnya dipajang dalam sebuah pameran, peneliti-praktisi memainkan peran peneliti dan melihat ke belakang pada proses artistik sebelumnya. Hal ini akan mendapatkan sebuah teori baru.

\section{DAFTAR PUSTAKA}

Guntur. (2016). Metode Penelitian Artistik, Surakarta, ISI Press

Kaelola, A. (2010). Mengenal Tokoh Wayang Mahabarata, Cakrawala

Saptodewo, F. (2014). Perancangan Visualisasi Tokoh Wayang Bambang Tetuka, Jakarta. Jurnal Desain Vol. 01 No. 02

(2016a). Mempopulerkan Cerita Pewayangan di Kalangan Generasi Muda Melalui Motion Comic, Jakarta. Jurnal Desain Vol. 02 No.03 ., (2016b). Pengembangan Karakter Wayang Tetuka untuk Pengembangan Cerita Saat Berada di Kawah Candradimuka, Jakarta. Jurnal Desain Vol. 03 No. 03 